\title{
Plastic Bags- Review on Problems and Remedies
}

\author{
Sunil Jayant Kulkarni \\ Datta Meghe College of Engineering, Airoli, Navi Mumbai, Maharashtra, India
}

*Corresponding Author: Sunil Jayant Kulkarni, Datta Meghe College of Engineering, Airoli, Navi Mumbai, Maharashtra, India

\begin{abstract}
The current paper focuses on specific plastic waste, plastic bags. A plastic bag, polybag, or pouch is a type of container made of thin, flexible, plastic film, nonwoven fabric, or plastic textile. Plastic bags are used for containing and transporting goods such as foods, produce, powders, ice, magazines, chemicals, and waste. It is a common form of packaging. It is most popular packing material. The environmental problems due to plastic are very serious. The no biodegradable nature of the plastic material is major concern. They clog water drainage. The irresponsible disposal of the plastic bags is considered one of the reasons for calamities like flooding.
\end{abstract}

Keywords: Treatment, recycle, reuse, disposal.

\section{INTRODUCTION}

Solid waste treatment is becoming major area of concern for ecological balance. The solid waste, if biodegradable can be treated satisfactorily by using various aerobic and anaerobic methods [1-4]. Also methods like digestion, composting, vermicomposting and anaerobic digestion are used for solid waste according to the composition of the waste and the requirement [5]. The waste from electronic industry can be reused and recycled. Plastic waste is one form of the solid waste which is increasingly becoming cause of concern. The reuse and recycling of the plastic is best option. Plastic can also be used in road construction [6-10]. The current paper focuses on specific plastic waste, plastic bags. A plastic bag, polybag, or pouch is a type of container made of thin, flexible, plastic film, nonwoven fabric, or plastic textile. Plastic bags are used for containing and transporting goods such as foods, produce, powders, ice, magazines, chemicals, and waste. It is a common form of packaging. It is most popular packing material. The environmental problems due to plastic are very serious. The no biodegradable nature of the plastic material is major concern. They clog water drainage. The irresponsible disposal of the plastic bags is considered one of the reasons for calamities like flooding.

\section{Plastic Bags- Review on Problems ANd Remedies}

Muthu et.al.studied eco-impact of plastic and paper shopping bags [11]. In their work they used the life cycle impact assessment (LCIA) technique. They carried out these studies for three options. The first option was related to usage and disposal criteria pertaining to present rules. Second one was usage and disposal criteria as per consumers' perceptions if systems are in place. The last third one was usage and disposal criteria in case of absence of recycling systems. The first phase was mainly related to the eco-impact of plastic and paper bags in the manufacturing phase. Here their use and usage related problems were not considered. They concluded that higher percentage of reuse could significantly trim down the eco-impact of plastic and paper bags. Camann et.al. carried out studies on plastic bags, their properties and their recycling[12].According to their estimates, in united states alone, 380 billion bags are used annually. According to their survey, only 1 percent is properly recycled. They carried out online survey and also surveys outside grocery surveys. They used accelerated aging through intense heat. In their work, for equivalent time of two hours, they analyzed the difference in mechanical properties before and after degradation under ambient conditions. Site visits and interviews were carried out by them to collect additional information. Their investigation indicated that both PE and biodegradable bags lost about 50\% of their original mechanical strength. Their survey also indicated that the cost of the degradable bags is major concern. An investigation was carried out by Gopal et.al. on plastic bags[13]. The problems of misuse and overuse and littering in India are major problem. Beside the visual pollution the plastic bags also are major factors in 
blockage of drainage line. Breeding of mosquitoes is another major aspect. In developing countries, plastic consumption and hence manufacturing is a concern. The reason for this is the fact the sophistication of the recycle and waste treatment facility has not taken place. Bell and Cave worked for comparison of plastic, paper and cloth bags on environment [14].Their studies indicated that contrarily to popular perceptions, paper in landfills does not degrade or break down at a substantially faster rate than plastic does. Adane and Muleta carried out case study on adverse impacts of plastic bags [15].Their studies were focused on Jimma City in Southwestern Ethiopia. They collected data from more than 200 respondents. Their survey indicated that the plastic bags are most abundantly used plastic material.They recommended use of non plastic bags made up of clothes. Bashir discussed plastic problems in Africa [16]. Plastics are most common materials in cars, bulletproof vests, toys, hospital equipment, and food containers. The increase in plastic use has many concerns. One is the consumption of natural resources such as oil. The manufacture and use of plastic is associated with some toxicity. Third is environmental impact associated with discarded plastic. According to them, PVC and PS - foam \& Styrofoam are two types of plastics which must be avoided. African countries have adopted some practices such as use of glass storage containers instead of plastic bags. Collection and recycling of waste plastic was discussed by Frane et.al.[17].They suggested improvements in existing collection and recycling systems.

\section{CONCLUSION}

Solid waste treatment is becoming major area of concern for ecological balance. The solid waste, if biodegradable can be treated satisfactorily by using various aerobic and anaerobic methods. Also methods like digestion, composting, vermicomposting and anaerobic digestion are used for solid waste according to the composition of the waste and the requirement. The waste from electronic industry can be reused and recycled. Plastic waste is one form of the solid waste which is increasingly becoming cause of concern. The reuse and recycling of the plastic is best option. Plastic can also be used in road construction. The current paper focuses on specific plastic waste, plastic bags.

\section{REFERENCES}

[1] Ravi P. Agrahari, G. N. Tiwari, "The Production of Biogas Using Kitchen Waste", International Journal of Energy Science, 2013, 3(6), 408-415.

[2] N.H.S.Ray, M.K.Mohanty, R.C.Mohanty, "Anaerobic Digestion of Kitchen Wastes:"Biogas Production and Pretreatment of Wastes, A Review", International Journal of Scientific and Research Publications, 2013, 3(11), 1-6.

[3] Rebecca Sebola, Habtom Tesfagiorgis, and Edison Muzenda, "Production of Biogasthrough Anaerobic Digestion of various Waste: Review", Intl' Conf. on Chemical, Integrated Waste Management and Environmental Engineering (ICCIWEE'2014) April 15-16, 2014 Johannesburg, 196-205.

[4] Sunil J. Kulkarni, "An Insight into Research and Studies on Biogas Generation from Waste", International Journal of Research \& Review (www.gkpublication.in) 78 Vol.3; Issue: 5; May 2016,pp.78-81.

[5] Meera T. Sose, Sunil J. Kulkarni, R. W. Gaikwad, Dr,TruptiCharpe, "Vermicomposting for Solid Waste Treatment",INt. Journal on Global Tech.Initiatives, Vol.5, No.1, 2016, ppC8-C13.

[6] Sunil J. Kulkarni, "A Review on Studies and Research on Use of Plastic Waste", International Journal of Research \& Review (www.gkpublication.in), Vol.2; Issue: 11; November 2015,692-696.

[7] Anselm E. O. Eneh, Application Of Recycled Plastics And Its Composites In The Built Environment, Best International Journal Of Management, Information Technology And Engineering, 2015, 3(3), 9-16.

[8] Mercy Joseph Poweth, Solly George, Jessy Paul, Study On Use Of Plastic Waste In Road Construction, International Journal Of Innovative Research In Science, Engineering And Technology, 2013, 2(2), 633638.

[9] Bhageerathy K. P, Anu P. Alex, Manju V. S, Raji A. K, Use Of Biomedical Plastic Waste In Bituminous Road Construction, International Journal Of Engineering And Advanced Technology, 2014, 3(6),89-92.

[10] Sasane Neha .B., Gaikwad.Harish, Dr. J R Patil And Dr. S D Khandekar, Application Of Waste Plastic As An Effective Construction Material In Flexible Pavement, International Research Journal Of Engineering And Technology,2015, 2(3),1943-1948.

[11] Subramanian Senthilkannan Muthu, Yi Li, , J.Y. Hu, P.Y. Mok, Xuemei Ding, Eco-Impact Of Plastic And Paper Shopping Bags, Journal Of Engineered Fibers And Fabrics, Volume 7, Issue 1 - 2012, 26-37.

[12] Andrew Camann,Kirk Dragsbaek,Stanley Krol,Jack Sandgren,David Song, Properties, Recycling And Alternatives To PE Bags, Worcester Polytechnic Institute,1-110. 
[13] N. M. Dana Gopal, P.Phebe1, E.V.Suresh Kumar, B.K.K.Vani, Impact Of Plastic Leading Environmental Pollution, National Seminar On Impact Of Toxic Metals, Minerals And Solvents Leading To Environmental Pollution-2014 Journal Of Chemical And Pharmaceutical Sciences, JCHPS Special Issue 3: October 2014, 96-99.

[14] Kirsty Bell and Suzie Cave, Comparison of Environmental Impact of Plastic, Paper and Cloth Bags, Research and Library Service Briefing Note, http://www.davidkrohn.net/what-are-the-impacts-of-plasticpaper-and-jute-bags-and-which-is-the-most-environmentally-friendly/, 1-8.

[15] Legesse Adane and Diriba Muleta, Survey on the usage of plastic bags, their disposal and adverse impacts on environment: A case study in Jimma City, Southwestern Ethiopia, Journal of Toxicology and Environmental Health Sciences Vol. 3(8) pp. 234-248, August 2011.

[16] Prof. Nabil H H Bashir, Plastic problem in Africa, Japanese Journal of Veterinary Research 61(Supplement): S1-S11, 2013.

[17] Anna Fråne, Åsa Stenmarck, Stefán Gíslason, Kari-Anne Lyng,Søren Løkke, Malin zu CastellRüdenhausen and Margareta Wahlström, Collection \& recycling of plastic waste Improvements in existing collection and recycling systems in the Nordic countries, www.norden.org/en/publications, TemaNord 2014:543.

\section{AUTHOR'S BIOGRAPHY}

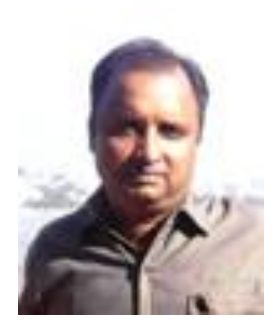

Mr. Sunil J. Kulkarni, has completed his Masters in Chemical Engineering from Tatyasaheb Kore Institute of Engineering and Technology, Warananagar in 2006. $\mathrm{He}$ is currently pursuing his $\mathrm{phD}$ in chemical engineering. $\mathrm{He}$ is working as Assistant Professor in Chemical Engineering Department of Datta Meghe College of Engineering, Airoli, Navi Mumbai, India. The author has 16 years of experience in teaching and research. He has published 200 international review and research papers and presented 15 research papers in international conferences. His area of research includes adsorption, environmental engineeringand catalysis. $\mathrm{He}$ is editorial boardmember of more than 25 international journals and reviewed many international papers.

Citation: S. Kulkarni, "Plastic Bags- Review on Problems and Remedies", International Journal of Advanced Research in Chemical Science (IJARCS), vol. 5, no. 1, pp. 1-3, 2018. http://dx.doi.org/10.20431/2349-0403.05 01001

Copyright: (c) 2018 Authors. This is an open-access article distributed under the terms of the Creative Commons Attribution License, which permits unrestricted use, distribution, and reproduction in any medium, provided the original author and source are credited. 